\title{
Development of Delay Factor Model for Substructure Works in Building Construction
}

\author{
Iwan Kurniawan ${ }^{1, *}$ Pungky Dharma Saputra ${ }^{1,2}$ Safri $^{3}$ Ridwan Saputro $^{1}$ \\ ${ }^{1}$ Civil Engineering Study Program, School of Engineering \& Technology, Tanri Abeng University, Jakarta, Indonesia \\ ${ }^{2}$ Military Building Construction Engineering, Faculty of Military Engineering, Indonesia Defense University, Bogor, \\ Indonesia \\ ${ }^{3}$ Civil Engineering Study Program, Faculty of Science and Technology, Institut Sains dan Teknologi Al-Kamal, \\ Jakarta, Indonesia \\ *Corresponding author. Email: iwan.kurniawan@student.tau.ac.id
}

\begin{abstract}
Building construction is one of the most complex construction hence construction delay is always happened. Substructure work is the first stage of building construction work. If a delay occurs in the substructure work stage, it will cause a snowball effect which can cause all of the building construction stage to be delayed. Therefore, research on the delay factor in substructure work is urgent to be mitigated at the beginning of the construction process. Identifying the delay factor is the main objective of this research. Furthermore, this research also tries to develop a model of delay factor in the substructure work stage. This research was conducted on high-risk building construction work, mix used area, and integrated with a railway station. The survey was conducted on 30 professional engineers in building constructions. This research was started in identifying the delay factor and analyzed using multiple regression methods to determine the influence of delay factors. The analysis showed that 13 delay factors that have a significant influence on project delay with a value of $\mathrm{p}<0,050$. The three highest correlated delay factors are government policy factor $(\mathrm{r}=0,880)$, construction work accident factor $(\mathrm{r}=0,847)$, and design factor $(\mathrm{r}=0,843)$. The identified delay factors can be intervened by mitigating that at the beginning of the project in order the future projects not to be late.
\end{abstract}

Keywords: Delay factors, Substructure Works, Building Construction.

\section{INTRODUCTION}

Building construction is one of the most complex constructions [1]. In the standardized work breakdown structure which had been developed, there are structure work, architecture works, mechanical, electrical, and plumbing works in level 2 [2]. Substructure works are in level 4 [2] and this is the beginning of building construction work. Therefore, the construction process should be given special attention in order not to be delayed.

Delay is additional time after the completion date which is agreed by parties [3]. Construction delay is a very important thing to be mitigated in a building construction project. One of the project goals is on time or not to be a delay. If a construction delay happens, it will have bad sustainable impacts such as cost overrun, quality problems, customer dissatisfaction, and company reputation.
There were so many delays factor which influence to construction delay. Previous study had identified the delay factors in various type of construction building. The delay factors had been identified are human resources aspects $[4,5,6,7,8,9,10]$, material aspects $[5,6,7,8,10]$, equipment aspects $[6,8,10,11]$, managerial aspects $[4,5,6,7,8,10]$, location characteristics aspects $[4,7,10,12]$, financial aspects $[4,5,7,8,10,11,13]$, physical aspects of buildings [5,12], design aspects [7,8,9,14], government policy aspects [7,10,11,15], document completeness aspects $[7,8,10]$, weather aspects $[6,7,16,17]$, unexpected events aspects [15], and work accidents aspects $[4,5,7]$.

There was so much research about construction delays. Recent research on construction delay in Indonesia only shows the project delay factor ranking in the construction industry [8]. Research on the model of construction delay had also conducted [18]. But, the research did not focus on substructure work in building construction. Even though it was previously explained 
that the substructure work in building construction is critical work that must not be delayed. Because it will create a snowball effect on the work afterward and cause delays to the entire project.

To complement previous research in construction delay, this research concern and focus on developing a delay factor model for substructure work in building construction. The delay factor model which will be produced in this research is expected to be a prediction model for construction delay, especially in building substructure works. Moreover, delay factors can be intervened by mitigating that at the beginning of the project in order the future projects not to be a delay.

\section{METHOD}

In answering research questions, this research was designed in 5 stages. This research was begun by identifying the variables through a literature review. Furthermore, these variables were validated by experts. Afterward, a survey was conducted on 30 respondents who were building construction practitioners. Then, the correlation analysis was conducted to determine the strength of the relationship between the delay factor variables and the construction delay as shown in Figure 1. In the final stage, the multiple linear regression analysis was used to determine the influence of the delay factor variable on construction delay and develop a prediction model. The research process is shown in Figure 2.

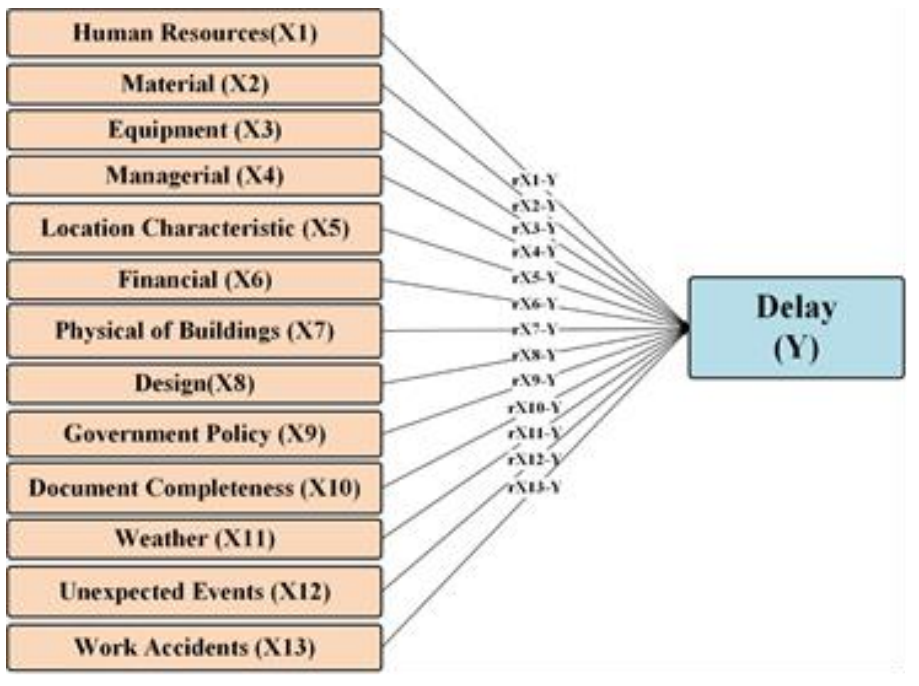

Figure 1 Relationship model between variables

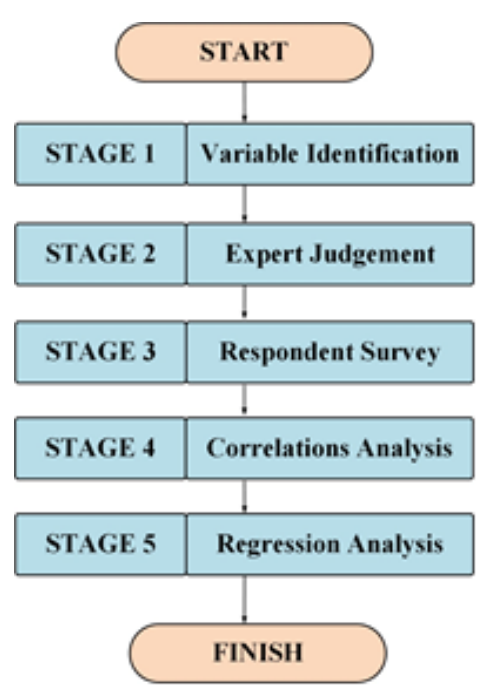

Figure 2 Research Process flow

\section{RESULT AND DISCUSSION}

\subsection{Expert Profile and Respondent Category}

This research requires experts to make judgments and validations to ensure that each variable has an influence or not. In this research, 5 main experts were asked for their opinions to validate the factors that influence construction delay. The profiles of experts including work experience, position, and final education are listed in Table 1 below.

Not only experts, but a survey of respondents was also conducted. 30 respondents were practitioners who were involved in building construction, they were also asked for their opinion. Respondent profiles including work experience, position, and final education are listed in Table 2 below.

Table 1. Profile of Expert

\begin{tabular}{llll}
\hline Expert & Working Experience & Position & Education \\
\hline Expert 1 & 19 Years & Team Leader & Master Degree \\
Expert 2 & 16 Years & Construction Manager & Master Degree \\
Expert 3 & 26 Years & Team Leader & Bachelor Degree \\
Expert 4 & 27 Years & Construction Manager & Master Degree \\
Expert 5 & 15 Years & Team Leader & Bachelor Degree \\
\hline
\end{tabular}


Table 2. Category of Respondents

\begin{tabular}{|c|c|c|c|c|c|c|c|c|}
\hline \multicolumn{3}{|c|}{ Category 1} & \multicolumn{3}{|c|}{ Category 2} & \multicolumn{3}{|c|}{ Category 3} \\
\hline No. & Education & $\begin{array}{l}\text { Total } \\
\text { Sample } \\
\end{array}$ & No. & $\begin{array}{l}\text { Working } \\
\text { Experience }\end{array}$ & $\begin{array}{l}\text { Total } \\
\text { Sample } \\
\end{array}$ & No. & Position & $\begin{array}{l}\text { Total } \\
\text { Sample } \\
\end{array}$ \\
\hline 1 & Bachelor Degree & 24 & 1 & $0-5$ Years & 10 & 1 & Engineer & 25 \\
\hline \multirow[t]{5}{*}{2} & Master Degree & 6 & 2 & $6-10$ Years & 12 & 2 & Team Leader & 5 \\
\hline & & & 3 & 11 - 15 Years & 4 & & & \\
\hline & & & 4 & $16-20$ Years & 0 & & & \\
\hline & & & 5 & $21-25$ Years & 2 & & & \\
\hline & & & 6 & 26 - 30 Years & 2 & & & \\
\hline \multicolumn{2}{|c|}{ Total Sample } & 30 & & & 30 & & & 30 \\
\hline
\end{tabular}

\subsection{Expert Judgement and Respondent Survey Results}

In this research, there were 13 factors or variables. Those were human resources aspects, material aspects, equipment aspects, managerial aspects, location characteristics aspects, financial aspects, physical aspects of buildings, design aspects, government policy aspects, document completeness aspects, weather aspects, unexpected events aspects, and work accidents aspects. The variables were identified from the literature review then validated by the expert and confirmed to the respondents which were practitioners.

The results of the expert judgment show that all variables or factors influence the construction delay because the value is greater than $50 \%$. The government policy variable is $54,67 \%$ and this is the lowest value in expert judgment analysis. The results of the respondent's survey also show the same thing, this shows that all variables or factors influence the construction delay because the value is greater than $50 \%$ and the government policy is also the lowest value of $63.13 \%$. The detailed results are shown in Table 3.

\subsection{Correlation analysis}

Correlation analysis aims to assess the strength of the relationship between variables. According to the analysis, it was found that variables of delay factors were related to the construction delay variable. This research ranked the variables with the highest to lowest correlation in Table 4. below. The three highest correlated delay factors were government policy aspects ( $\mathrm{r}=0.880)$, construction work accident aspects $(\mathrm{r}=0.847)$, and design aspects $(\mathrm{r}=0.843)$. Weather aspects were correlated [8] but it was the lowest $(\mathrm{r}=0.588)$.

Table 3. Experts' judgment and respondent survey results

\begin{tabular}{|c|c|c|c|c|c|c|c|}
\hline \multirow{2}{*}{ No } & \multirow{2}{*}{ Validated Factor } & \multicolumn{2}{|c|}{ Expert Judgement } & \multicolumn{4}{|c|}{ Respondent Survey } \\
\hline & & Yes & No & Remark & Yes & No & Remark \\
\hline 1 & Human Resources Aspects & $86.29 \%$ & $13.71 \%$ & Influence & $81.88 \%$ & $18.13 \%$ & Influenc \\
\hline 2 & Material Aspect & $80.57 \%$ & $19.43 \%$ & Influence & $85.00 \%$ & $15.00 \%$ & Influence \\
\hline 3 & Equipment Aspects & $85.33 \%$ & $14.67 \%$ & Influence & $79.38 \%$ & $20.63 \%$ & Influence \\
\hline 4 & Managerial Aspects & $83.00 \%$ & $17.00 \%$ & Influence & $85.00 \%$ & $15.00 \%$ & Influence \\
\hline 5 & $\begin{array}{l}\text { Location } \quad \text { Characteristic } \\
\text { Aspects }\end{array}$ & $67.43 \%$ & $32.57 \%$ & Influence & $73.75 \%$ & $26.25 \%$ & Influence \\
\hline 6 & Financial Aspects & $72.00 \%$ & $28.00 \%$ & Influence & $79.38 \%$ & $20.63 \%$ & Influence \\
\hline 7 & $\begin{array}{l}\text { Physical Aspects } \\
\text { Buildings }\end{array}$ & $59.00 \%$ & $41.00 \%$ & Influence & $65.63 \%$ & $34.38 \%$ & Influence \\
\hline 8 & Design Aspects & $84.80 \%$ & $15.20 \%$ & Influence & $80.63 \%$ & $19.38 \%$ & Influence \\
\hline 9 & Government Policy Aspects & $54.67 \%$ & $45.33 \%$ & Influence & $63.13 \%$ & $36.88 \%$ & Influence \\
\hline 10 & $\begin{array}{l}\text { Document Completeness } \\
\text { Aspects }\end{array}$ & $76.00 \%$ & $24.00 \%$ & Influence & $78.13 \%$ & $21.88 \%$ & Influence \\
\hline 11 & Weather Aspects & $73.33 \%$ & $26.67 \%$ & Influence & $78.75 \%$ & $21.25 \%$ & Influence \\
\hline 12 & Unexpected Events Aspects & $91.20 \%$ & $8.80 \%$ & Influence & $82.50 \%$ & $17.50 \%$ & Influence \\
\hline 13 & Work Accidents Aspects & $89.33 \%$ & $10.67 \%$ & Influence & $77.50 \%$ & $22.50 \%$ & Influence \\
\hline
\end{tabular}


Table 4. Rating of the delay factor

\begin{tabular}{lllll} 
No. & Code & Variable & Correlation & Rank \\
\hline 1 & X9 & Government Policy Aspects & 0.880 & 1 \\
2 & X13 & Work Accidents Aspects & 0.847 & 2 \\
3 & X8 & Design Aspects & 0.843 & 3 \\
4 & X10 & Document Completeness Aspects & 0.838 & 4 \\
5 & X7 & Physical Aspects of Buildings & 0.828 & 5 \\
6 & X5 & Location Characteristic Aspects & 0.774 & 6 \\
7 & X6 & Financial Aspects & 0.749 & 7 \\
8 & X2 & Material Aspect & 0.723 & 8 \\
9 & X1 & Human Resources Aspects & 0.659 & 9 \\
10 & X3 & Equipment Aspects & 0.642 & 10 \\
11 & X4 & Managerial Aspects & 0.631 & 11 \\
12 & X12 & Unexpected Events Aspects & 0.616 & 12 \\
13 & X11 & Weather Aspects & 0.588 & 13 \\
\hline
\end{tabular}

\subsection{Multiple Regression Model}

The analysis result in Table 5. shows that the value of $\mathrm{R}$ is 0,988 . This value shows that all variables of the delay factor are correlated to the construction delay variable. The result of the analysis also shows that the $\mathrm{R}^{2}$ value is $0,997(99,7 \%)$. It shows that $99,7 \%$ of the diversity of the construction delay variable can be explained by all variables of the delay factor. And the remaining 0,30\% can be explained by other variables outside the model. ANOVA in Table 6. shows that the significant level is Table 6. ANOVA
$0,000<0,050$, which means all variables of delay factors influence construction delay simultaneously and coefficient of variable in Table 7 .

Table 5. Regression Output

\begin{tabular}{llllc} 
Model & $\mathbf{R}$ & $\begin{array}{l}\text { R } \\
\text { Square }\end{array}$ & $\begin{array}{l}\text { Adjusted } \\
\text { R Square }\end{array}$ & $\begin{array}{c}\text { Std. Error } \\
\text { of the } \\
\text { Estimate }\end{array}$ \\
\hline 1 & $0.998^{\mathrm{a}}$ & 0.997 & 0.994 & 0.842446 \\
\hline
\end{tabular}

\begin{tabular}{lllllll}
\hline Model & Sum of Squares & df & Mean Square & F & Sig \\
\hline 1 & Regression & 3821.794 & 13 & 293.984 & 414.228 & $0.000^{\mathrm{a}}$ \\
& Residual & 12.775 & 18 & 0.710 & & \\
& Total & 3834.569 & 31 & & & \\
\hline
\end{tabular}

Table 7. Coefficient of variables

\begin{tabular}{|c|c|c|c|c|c|c|}
\hline & \multirow{2}{*}{ Model } & \multicolumn{2}{|c|}{ Unstandardized Coefficients } & \multirow{2}{*}{$\begin{array}{c}\text { Standardized } \\
\text { Coefficients } \\
\text { Beta } \\
\end{array}$} & \multirow[t]{2}{*}{$\mathbf{t}$} & \multirow[t]{2}{*}{ Sig. } \\
\hline & & B & Std. Error & & & \\
\hline \multirow[t]{14}{*}{1} & (Constant) & -3.458 & 2.358 & & -1.467 & 0.160 \\
\hline & $\mathrm{X} 1$ & 0.087 & 0.028 & 0.081 & 3.147 & 0.006 \\
\hline & $\mathrm{X} 2$ & 0.134 & 0.037 & 0.116 & 3.591 & 0.002 \\
\hline & $\mathrm{X} 3$ & 0.051 & 0.023 & 0.068 & 2.245 & 0.038 \\
\hline & $\mathrm{X} 4$ & 0.089 & 0.037 & 0.073 & 2.413 & 0.027 \\
\hline & X5 & 0.071 & 0.021 & 0.097 & 3.317 & 0.004 \\
\hline & X6 & 0.087 & 0.017 & 0.127 & 5.170 & 0.000 \\
\hline & $\mathrm{X} 7$ & 0.088 & 0.017 & 0.156 & 5.160 & 0.000 \\
\hline & $\mathrm{X} 8$ & 0.095 & 0.029 & 0.098 & 3.228 & 0.005 \\
\hline & X9 & 0.053 & 0.019 & 0.093 & 2.878 & 0.010 \\
\hline & $\mathrm{X} 10$ & 0.051 & 0.022 & 0.072 & 2.295 & 0.034 \\
\hline & $\mathrm{X} 11$ & 0.065 & 0.021 & 0.070 & 3.090 & 0.006 \\
\hline & $\mathrm{X} 12$ & 0.084 & 0.019 & 0.108 & 4.331 & 0.000 \\
\hline & $\mathrm{X} 13$ & 0.085 & 0.015 & 0.163 & 5.609 & 0.000 \\
\hline
\end{tabular}


T-test or regression coefficient test results show that all variables of delay factor significantly influence the construction delay with all of the p-value less than 0,050 . The detail of the regression coefficient test results can be seen in Table 7 . These results produce the mathematical equation of a multiple linear regression model as follow:

$$
\begin{aligned}
Y= & -3,458+0,087 X 1+0,134 X 2+0,051 X 3+ \\
& 0,089 X 4+0,071 X 5+0,087 X 6+0,088 X 7+ \\
& 0,095 X 8+0,053 X 9+0,051 X 10+0,065 X 11 \\
& +0,084 X 12+0,085 X 13
\end{aligned}
$$

Human resources influence construction delay significantly $(\mathrm{p}=0,060)$. Human resources is a schedule delay indicator [7]. Human resource in a project is based on labor skill [5,6,10] and technical staff skill [9] and will determine labor productivity [8]. Construction manager experience also shows subcontractor competency [4] to prevent construction delays. Material is also a very important thing to support project construction which influences the construction delay significantly $(\mathrm{p}=0,020)$. Late delivery of materials is a fatal mistake and makes the project delay $[5,6,7,8,10]$. Besides the material, the equipment must also be made site breakdown [10] and delivered on time $[6,8,10,11]$ because it influences the project delay significantly $(\mathrm{p}=0,038)$.

To be on the schedule, owner management [5], contractor management [10], subcontractor management $[8,9]$, and site management [6] should be great. Because management aspects influence construction delay very significantly $(\mathrm{p}=0,027)$. Finance is also a determinant of project delays $(\mathrm{p}=0,000)$. Delay in payment to the contractor $[7,8,10,11,13]$ shows payment shows the owner's financial ability is very bad [4,5] and causes the project delay. Document completeness aspect is a part of the owner and or contractor management. Delay in approval document submittal and the drawing will cause construction delay $[7,8,10]$ with a significant level $\mathrm{p}=0,034$.

Characteristics of location or project area are site constraints [12]. The location or project area is also a determinant of project delay $[4,7,10]$ with a significant level $\mathrm{p}=0,004$. Different project locations also cause different climates and weather. Climate [17] and weather $[6,7,16]$ during project construction can cause project delays with a significant level of $p=0,006$. Project location and climate sometimes cause unexpected events such as disasters. This is an act of God and has a very significant effect on construction delay [15] with a value of $p=0,000$. Location is a determinant of the design and physical form of the building. These influence the project delays significantly with a significant level of $\mathrm{p}=0,005$ for design and $\mathrm{p}=0,000$ for physical aspects of buildings. Data collection and surveys must be conducted properly [9], hence there are not many design changes $[7,8,14]$ that can cause project delays. An efficient design should be considered to determine project type [12] and project complexity [5] which can cause project delays.

Government policy influence construction delay significantly $[4,7,10,11]$ with significant level $\mathrm{p}=0,010$. Government policy consists of politics [4,7,11], law [4], bureaucracy [4], and government action [4]. Government policies also relate to project locations such as different countries, provinces, and cities

The last factor is a factor related to construction safety. Poor construction site safety management can cause construction accidents [5,7]. And automatically the project will be stopped for accident investigation. Thus, project accidents greatly affect project delays [4] with a significant level $\mathrm{p}=0,000$.

\section{CONCLUSION}

The three highest correlated delay factors are government policy aspects $(r=0,880)$, construction work accident aspects $(\mathrm{r}=0,847)$, and design aspects $(\mathrm{r}=0,843)$. Human resources aspects, material aspects, equipment aspects, managerial aspects, location characteristics aspects, financial aspects, physical aspects of buildings, design aspects, government policy aspects, document completeness aspects, weather aspects, unexpected events aspects, and work accidents aspects are variables which significantly influence the construction delay in building substructure work. The identified delay factors can be intervened by mitigating that at the beginning of the project in order the future projects not to be late. This research is necessary to be developed by analyzing the influence of delay factors towards delay impacts in building construction projects, especially in substructure work.

\section{ACKNOWLEDGMENTS}

The authors would like to thank experts, respondents, advisors, research team, research funder, and all those who contribute materially and morally in finishing this research.

\section{REFERENCES}

[1] D. Lee, H. Lim, D. Lee, H. Cho, K. Kang. "Assessment of Delay Factors for Structural Frameworks in Free-form Tall Buildings Using the FMEA", International Journal of Concrete Structures and Materials, 13:2, 2019.

[2] V. Elsye, Y. Latief, L. Sagita, L, "Development of Work Breakdown Structure (WBS) Standard for Producing the Risk Based Structural Work Safety Plan Of Building." MATEC Web of Conferences, 147, 2018. 
[3] S. A. Assaf, S. Al-Hejji, "Causes of delay in large construction projects", International Journal of Project Management, 24, 349-357, 2006.

[4] M. S. Islam, B. T. Suhariadi, "Construction delays in privately funded large building projects in Bangladesh", Asian J Civ Eng 19, 415-429, 2018.

[5] S. Durdyev, M. Omarov, S. Ismail, "Causes of delay in residential construction projects in Cambodia", Cogent Engineering, 4:1, 1291117, 2017.

[6] M. Z. Ramli, M A Malek, M. H. Hanipah, C. L. Lin, M. F. M. Sukri, M. H. Zawawi, M. Z. Z. Abidin, N. F. S. M. Fuad, "Study of factors influencing construction delays at rural area in Malaysia", International PostGraduate Conference on Applied Science \& Physics 2017, IOP Conf. Series: Journal of Physics: Conf. Series 1049, 012017, 2017.

[7] E. Safapour, S. Kermanshachi, B. Alfasi, R. Akhavian, "Identification of Schedule-Performance Indicators and Delay-Recovery Strategies for LowCost Housing Projects", Sustainability 11, 6005, 2019.

[8] Ade Asmi, A. Djamaris, M. Ihsan, “Top Ten Similarity Ranking for Project Delay Factors in Construction Industry", First International Conference of Construction, Infrastructure, and Materials IOP Conf. Ser.: Mater. Sci. Eng. 650 012006, 2019.

[9] Q. Bux alias I. Latif, A. M. D. Al Saadi, I. A. Rahman, "Identification of Delay Factor in Oman Construction Industry," International Journal of Sustainable Construction Engineering and Technology, Vol. 10 No. 1, 34-45, 2019.

[10] J. A. Alsuliman, "Causes of delay in Saudi public construction Projects", Alexandria Engineering Journa, 58, 801-808, 2019.

[11] Mahamid, A. Bruland, N. Dmaidi, "Causes of Delay in Road Construction Projects", Journal of Management in Engineering, Vol 28, 3, 2012.
[12] M. Z. Ramli, M. A. Malek, B. Hamid, N. T. Roslin, M. E. M. Roslan, S. Norhisham and M. F. Mohd, "Influence of Project Type, Location and Area towards Construction Delay: a Review on Significance Level of Delay Factors" International Journal of Engineering \& Technology, 7 ,4.35, 392 399, 2018.

[13] S. Kasemsukh, N. Kokkaew, "Financial Impact Assessment of Construction Delay in BOT Infrastructure Projects”, International Conference on Construction and Real Estate Management, 2020.

[14] M. Tafazzoli, P. Shrestha, "Factor Analysis of Construction Delays in the U.S. Construction Industry", International Conference on Sustainable Infrastructure, 2017

[15] F. D. K. Fugar, A. B. Agyakwah-Baah, "Delays in Building Construction Projects in Ghana", Australasian Journal of Construction Economics and Building, 10 (1/2) 103-116, 2010.

[16] S. Apipattanavis, K. Sabol, K. R. Molenaar, B. Rajagopalan, Y. Xi, B. Blackard; and S. Patil, "Integrated Framework for Quantifying and Predicting Weather-Related Highway Construction Delays", Journal of Construction Engineering and Management, Vol. 136, 11, 2010.

[17] P. Ballesteros-Pérez, M. L. del Campo-Hitschfeld, M. A.González-Naranjo and M. C. González-Cruz. "Climate and construction delays: case study in Chile", Engineering, Construction and Architectural Management, Vol. 22 No. 6, 596-621, 2015.

[18] M. Z. Ramli, M. A. Malek, M. Z. Muda, Z. A. Talib, N. S. Azman, N. F. S. M. Fu'ad, M. H. Zawawi, and H. Y. Katman. "A Review of Structural Equation Model for Construction Delay Study", International Journal of Engineering \& Technology, 7, 4.35, 299306, 2018. 